\title{
Factors Influencing Employee Retention: A Karachi Based Comparative Study on IT and Banking Industry
}

\author{
Ms Shahtaj Yousuf (Corresponding author) \\ Karachi University Business School, University of Karachi \\ Main University Road Karachi - 75270 Sindh, Pakistan \\ E-mail: shahtajessani@gmail.com \\ Dr Danish Ahmed Siddqui \\ Karachi University Business School, University of Karachi \\ Main University Road Karachi - 75270 Sindh, Pakistan \\ E-mail: Daanish79@hotmail.com
}

Received: Nov. 19, 2018 Accepted: Dec. 7, 2018 Online published: Dec. 25, 2018

doi:10.5296/ijhrs.v9i1.14111 URL: https://doi.org/10.5296/ijhrs.v9i1.14111

\begin{abstract}
The purpose of this study is to explain the factors that help in retaining employees in IT and banking industry. These factors include performance appraisals, training and development and workplace environment. It is important to learn how different organizations use these variables as tools to keep their employees satisfied and preserved. In order to carry out this research, a count of 120 questionnaires were distributed among the respective officials in various IT companies and banks. SPSS software was used to analyse the received data to find the relationship between employee retention and these three factors. The study explains that some variables such as performance appraisal, training and development and work environment largely affect the rate of employee retention. Results showed that performance appraisal has a significantly more impact on the retention rate of the employees working in IT sector whereas in banking sector training and development has more influence on retention rate. And through conducting a survey from employees working in these sectors, it is verified that banking and IT industries are also focusing on employee retention management. The academic implication of this research is that academicians should introduce the separate course of employee retention or retention management for the students of HR major as this area is gaining attention of not only researchers, but also of corporate world practitioners. And the practical implication of this
\end{abstract}


research includes the importance of employee retention in the local and global competitive market. The practitioners must understand the worth of retention factors so that they can compete nationally and globally by effectively implementing them in retention strategies. They must work out for their employees as employees are the organization's prior customers and satisfied employees can satisfy the organization's customers.

Keywords: employee retention, retention factors, performance appraisal, training and development, work environment

\section{Introduction}

Employee retention is the escalating concept for many organizations. Organizations and managers believe that long-term success, survival and productivity of an organization rely upon the ability to retain best and valuable employees (Das \& Baruah, 2013). This point has drawn the attention of many researchers in recent years to conduct study on the reasons behind employees' intention to leave and intention to stay within any organization. Researchers have understood the importance of employee retention earlier than many organizations and conveyed the significance to employers as well through their study (Christensen Hughes \& Rog, 2008; Lam, Law, Loo, Ng, \& Ooi, 2015; Mabuza \& Proches, 2014; Nyanjom, 2013; Padmanathan \& Newell, 2012; Sinha \& Sinha, 2012; Tiwari, 2015; Zin et al., 2012).

Lam et al. (2015) cited that Talent retention or employee retention refers to the amount of time that an employee spends in an organization. They stated that employee retention not only reflects the steadiness of employment within an organization, but it also displays the propensity of an employee to work in one organization for a long time. This steadiness of employment depends on the satisfaction and opportunities an employee feel and receive within any organization. Satisfaction of an employee depends upon multiple factors such as a handsome compensation package, fringe benefits, flexible working hours, empowerment, training and career development, growth, and learning opportunities, fair and unbiased appraisal system, friendly working environment, etc. (Eyster, Johnson, \& Toder, 2008; Kossivi, Xu, \& Kalgora, 2016; Loan-Clarke, Arnold, Coombs, Hartley, \& Bosley, 2010; Mabuza \& Proches, 2014; Naeem \& Saif, 2010; Nyanjom, 2013; Sinha \& Sinha, 2012). Different organizations adopt different factors by formulating various strategies to retain their valuable resources.

Nyanjom (2013) consider employees as the important resource as they contribute their efforts and knowledge in achieving the organization's goals, objectives and missions. Hence it is important to retain them for the development and accomplishment of the organizational goals, objectives and missions specifically in gaining competitive advantage over the competitors in the era of globalization.

Retaining employees is known to be one of the foremost challenge organizations confronting today. Attracting and acquiring competent talent is undeniably a critical task, but retaining them is way more difficult than that. To worsen the situation, globalization has contributed a lot as employees are not only ready but also willing to relocate and change jobs in any part all 
over the world. It has been on high priority of many organizations and other profit generating organizations within this country, however, its acceptance by IT and banking industry has been less prominent. In this study, two most economic and running sectors, IT and Banking are selected as a setting to conduct the comparative research on employee retention because other sectors are previously studied such as mental healthcare, a state corporation in Kenya, heavy engineering industry, hospitality, energy, nursing industry, and Small and medium enterprise (SME) sectors (Christensen Hughes \& Rog, 2008; Lam et al., 2015; Mabuza \& Proches, 2014; Nyanjom, 2013; Padmanathan \& Newell, 2012; Sinha \& Sinha, 2012; Tiwari, 2015; Zin et al., 2012). Therefore, to identify different factors influencing employee retention and how they are adopted by organizations as a tool of retaining talents, a comparative study is conducted among IT and banking industry.

This research covers the concept of employee retention and its importance in IT and Banking sector in detail. All researchers tend to elaborate the concept of employee retention differently because of the difference in perspectives. Some organizations believe that employee retention helps an organization to avoid the cost spent on hiring and training new employees when the older ones leave it, while other consider it as an approach to improve the performance of an organization and workforce productivity and satisfaction.

Retaining key employees is vital for the survival and success of any organization. The employees need to be managed with great care because they are the most important and complex resource. The only way for organizations to retain the employees is to meet their current need. According to Workforce Planning, the organization needs a systematic approach to establish an environment that will help the workers with their varying needs for them to continue working for the company. This step will lead to success and growth.

The team leaders, supervisors, managers, and especially HR professionals need to realize the importance of employee retention in this competitive environment. They must consider the factors that have a positive effect on employee retention. Therefore, managers and strategists should use these influencing factors while formulating strategies and align them with business strategies as well to retain valuable employees for a longer period of time.

This study elaborates the factors and causes having a substantial effect on employee retention. These factors may be tangible - monetary and non-monetary, or intangible in nature. Some special strategies including these factors are designed and implemented in order to keep the level of employees' performance high over an extended period of time. The research is applied to IT and Banking sector so as to conduct comparative analysis to get better insight of the factors that make employees more frequent to leave or stay in the organization. These factors are also considered in formulating strategies for developing employees and fulfilling their emerging needs.

\subsection{Research Problem}

In this country, firms and other profit-oriented businesses are working on employee retention, but its discussion in IT and banking sectors is not as prominent. Numerous studies were conducted upon the various industries all over the world, such as mental healthcare, the 


\section{Macrothink}

International Journal of Human Resource Studies

ISSN 2162-3058 2019, Vol. 9, No. 1

Kenyan state corporation, heavy engineering industry, hospitality, energy, nursing industry, and Small and medium enterprise (SME) sectors, (Christensen Hughes \& Rog, 2008; Lam et al., 2015; Mabuza \& Proches, 2014; Nyanjom, 2013; Padmanathan \& Newell, 2012; Sinha \& Sinha, 2012; Tiwari, 2015; Zin et al., 2012) but literature lack studies on employee retention within Banking and IT sectors. Thus, this research aimed to conduct comparative study on most economic contributing sectors; IT and banking sectors within Karachi for identifying the influence of selective variables on employee retention. This is the reason approximately 120 officials (60 from IT and 60 from banking sector) were chosen to give feedback about employee retention and factors that have an impact on it. It is important to learn how organizations are implementing the retention factors in order to retain important employees. Banks and IT companies are important not only because of the services that they provide to both clients and public but also because of their fair share in the progress and welfare of the country.

\subsection{Research Objectives}

The major aim of this exploration is to analyse the reasons that impact employee retention in IT and banking sectors. These sectors tend to face many issues in preserving high talent which results in a high turnover rate, and also has a negative effect on the progress of organizations. The Study will analyse how employees perceive their work and the causes that lead them to quit an organization. By doing it, the study will describe the following:

(1) The importance of employee retention.

(2) The factors that affect the retention of employees.

(3) The effect of certain factors on employee retention.

\subsection{Hypotheses}

H1: There is a significant impact of Performance Appraisal on employee retention in IT industry.

H2: There is a significant impact of Training and Development on employee retention in IT industry.

H3: There is a significant impact of Working Environment on employee retention in IT industry.

H4: There is a significant impact of Performance Appraisal on employee retention in the banking sector.

H5: There is a significant impact of Training and Development on employee retention in the banking sector.

H6: There is a significant impact of Working Environment on employee retention in the banking sector. 


\subsection{Significance of the Study}

This study will describe the effective worker retention strategies, which will widen the circle of awareness about its impact on an organization's success. Its role has been noteworthy in many industries especially IT and banking industry. In IT industry, team members are managed and preserved through an actively played role by project managers, supervisors and team leads while in banking industry two more hierarchical levels are involved that are management in the head office and on branch end.

The study will give its input to improve the understanding of the subject of employee retention and HR management. It is important because it will:

(1) Identify the employee retention aspects and methods in IT and banking sector.

(2) Help organizations understand that having effective and practical employee retention strategies is the key to a successful organization.

(3) Deliver valuable information about factors that influence employee satisfaction and their intent to leave an organization

Research will explain the good and bad effects of employee retention which will help IT and bank managers to use retention factors in an efficient way to keep a steady staff thus reducing rapid employee turnover. Moreover, the study is going to explore the causes of employee retention in banks and IT companies. . Providing new evidence, this research thus serves as reference and supplementary literature review for future research on the related subject matter.

\section{Literature Review}

Employee retention is defined as "a practice, companies adopted to maintain an effective workforce and simultaneously meet operational requirements" (Kossivi et al., 2016). As companies now understand the importance of employee retention and the worth of key employees, managers and team leads are formulating various employee retention strategies by taking into account the different retention factors that are influencing employees' intention to stay within the organization. Das and Baruah (2013) also described employee retention as "a process in which the employees are encouraged to linger with the firm for the longer time period or till the project is completed". Since the departure of employees from an organization can affect its performance and profitability negatively, the most important cause of employee retention is to help prevent it, (Samuel \& Chipunza, 2009). Therefore, organizations will face fewer turnovers and abide less employee-related cost.

Essays (November 2013) cited that employee retention is mainly done in order to benefit the organization, however, retention is explained in terms of "some notion of adequacy or sufficiency of length of service", which relates to the vital effects on customer care or the expenditure used in hiring and training. Keeping this in mind, the retention factors need to be considered that are having a significant impact on the employee retention within any company. As per Government (2015), the retention of an employee is "an effort to produce and nurture an environment systematically that motivates employees to endure employment by having policies and practices in place, addressing their diverse needs". It deals with the 
idea of keeping employees motivated to remain in an organization as a working body for longer time period. This motivation needs handling of various factors and strategies for its efficient execution.

Employee retention, as stated earlier, is not influence by any single factor, but influencers exist in bulk. This needs to be understood by employers, that satisfied employees are more valuable than satisfied customers. Contented employees of your organization will give their best to satisfy your customers, only when they themselves are gratified. Therefore, organizations should work on more factors instead of taking into account a single factor and formulate strategy accordingly. This will outlay them in the race of competition and will end up losing their high potential employees to their rivalries.

\subsection{Importance of Employee Retention}

This era holds a substantial significance for employee retention. In order to make an organization effective and profitable, employee retention methods must be a priority. This discussion has been continued since a long period of time and many researchers and experienced professionals have supported it through their researches. Many researches focus on the cost borne by organizations when an employee leaves, as it is one of the major concerns of employers. Nyanjom (2013) cited that an average company faces a loss of around $\$ 100,000$ every time a professional of managerial employee leaves it, making turnover extremely costly for it (Torrington \& Taylor, 2009)

HR managers are compelled to attract and retain competent employees with certain competencies that are crucial for the survival of the organization. De Vos and Meganck (2008) stated that these employees more focus on establishing their own career path rather than being loyal to the organization, thus they are more difficult to retain. Some of the researchers in the field of business management and specially HR, debate that for effective retention management, creating the finest portfolio of HR practices is not only essential, but also managing employees' perceptions regarding their organization's promises for returning them for their loyalty and commitment is important.

Retention not only benefits the employees, but it has a long term positive impact and advantage to the organization as well. Preserving employees for longer tenure not only increase the profitability of the organization but contributes largely in maintaining the market image and a reputation of the company. This increases the trust of companies' potential customers, clients and applicants. This also generates the larger talent pool for the future vacant positions in the organization. Nyanjom (2013) stated that firms want top talents to stay for their up to date skills and knowledge but the demand for such talented employees has increased significantly. Additionally, recruitment techniques used by the competitors have become increasingly aggressive to get valuable talents. It also ensures the loyalty and dedication of the future employees towards the organization as previous and current employees will recommend their friends and beloved one to be a part of their organization. This will happen as a result of their satisfied diverse needs and professional growth. 


\subsection{Factors Affecting Employee Retention}

Retaining employees is not only about granting them with promotion and a noticeable raise in their basic salary at the end of the year, however, it has lot more dimensions that need to be catered timely. Many companies as per their policy, a budget, nature of the business and nature of the job performed by the employees, consider certain factors. Basically, factors are the causes and influences that are taken into consideration while formulating and implementing the employee retention strategy of an organization. The factors can be either tangible or intangible. Both forms have their own significance and impact on the employees' psychology and their intent to stay within the organization.

As different organizations have distinctive factors to retain their employees, likewise different researchers have different conceptions for the factors that influence employee retention. Training also works as one of the key factors that help in retaining employees of any age. Enabling access to training and development programs available for all employees stimulate the progress of organization, specifically with technological and performance developments (Authority, 2009).

As the ownership increases the chances of job's success rate and ownership can only be created among employees by empowering them and with autonomous opportunities. Naeem and Saif (2010) mentioned that empowering the employees creates feelings of belonging and ownership for the current organization. It makes employees more confident and helps them to perform better.

The leadership style and the way the people are managed within organizations highly influence the decision of employees regarding staying in the organization. Leadership and their relationship with their immediate supervisors affect significantly work satisfaction and motivation level among the employees. Hong, Hao, Kumar, Ramendran, and Kadiresan (2012) cited that according to some researches, the factors leading to turnover include low levels of empowerment, low levels of support of superiors and lack of job dissatisfaction. According to Kossivi et al. (2016), employee retention has affected by management and can be viewed from two different perspectives; management's support and leadership style.

In the sphere of employee retention, conduce work environment seems to be an essential influencer (Kossivi et al., 2016). Conducive work environment includes flexibility, enjoyable workplace settings, and adequate resources. Various researchers have been putting light on significant influence of work environment on the retention rate of employees. Nyanjom (2013) cited that employers work on changing unsatisfactory working conditions that can cause employees to leave an organization. Changing these work conditions improves the satisfaction level of employees and changes their decision to leave into a decision to stay, and the possibility increases that the employees will choose to stay with their current organization.

At any age, skills recognition through individual work achievements works as an effective strategy (Yazinski, 2009). Further, Sinha and Sinha (2012) cited that it has been indicated by the researches that recognition of personal job accomplishments makes people feel accepted 
and thus increases the employment span. Nyanjom (2013) cited that the management is responsible to recognize talented employees with good performance and acknowledge them on merit in every way, including financial rewards. Poor benefits and reduced compensation also result in the rise in voluntary turnover rate. The same conditions that make employees leave; also make it tough to recruit new replacements.

It is quite a unique challenge for companies to create a compensation structure in order to support the employee development programs. The organizations tend to claim that pay raises are based on performance but that is not really the case. Sinha and Sinha (2012) cited that some organizations try to put focus on team work but keep rewarding people for personal accomplishments. Such contradictions can make employees sceptic and frustrated. Many researchers suggest that employee retention is largely affected by compensation satisfaction. Nyanjom (2013) cited that employees tend to remain loyal to an organization if they are contented with the operations and compensation structure of the company.

Flexibility and freedom towards working hours is proved to be one of the most influencing factors. It is important to retain employees of any age (Authority, 2009). Researches prove employees of all ages like having a balance between work and personal lives and "flexibility" at work allows them to achieve that. This flexibility at work can has different dimensions such as working hours, working shifts, and work from home. This enable employees to stay within the organization as organization provides them with the best possible convenience to balance their work and personal life.

As employees want various career development opportunities for their professional growth, they switch the organizations whenever an attractive opening comes their way. Sinha and Sinha (2012) cited that retention of talented employees critically requires a number of development and learning opportunities, thus it is necessary for an organization to have a supportive working and learning environment. According to Eyster et al. (2008) employees perceive job flexibility with worthwhile life and career options as a critical incentive. Therefore, organizations should formulate strategies in such a manner that provides them competitive advantage along with the career growth opportunities for the development and rise in employees' career ladder.

Unbiased and fair appraisal system can play a vital role in establishing a feeling of trust within employees for their employers. Appraisal system can vary company to company. Nyanjom (2013) cited that it is a procedure to understand and evaluate an employee's performance in order to make the decision about his or her career development. It evaluates his or her ability to seek higher positions, characteristics and working performance in organization, in order to assess his or her total involvement in the organization (Gruman \& Saks, 2011). An effective appraisal will help to company better understand employee satisfaction level as well as improve employee development through feedback.

Nyanjom (2013) cited that many researches by social exchange theorists elaborate how an employee's commitment to an organization is directly related to the commitment shown by the organization to that employee. The attitudes, behaviours and even performances of employees reflect what they perceive and expect from the organization, depending upon how 
they are treated by the organization. Moreover, Nyanjom (2013) cited that employee retention can be improved by high-involvement work practices.

\subsection{Factors Affecting Employee Turnover}

Katavich (2013) cited that there are many causes behind an individual leaving an organization which may range from: job (e.g., role overload), individual (e.g., age), social factors (e.g., economic law reforms) and organizational (e.g., company policies and practices). Another positive side of the cited research included quantitative findings about how many organizations have the power to implement strategies and practices created to make employees more empowered and thus decrease the turnover rate.

Moreover, it is more useful for organizations to research upon are the reasons that make employee intent to resign from the current employment relatively than the certain turnover (Brown, Hyatt, \& Benson, 2010). Katavich (2013) cited that the reason behind the debate is that the decision of turnout is said to be a result of a gradual thought process, which includes the thought of leaving becoming appealing to the clients, which leads to serious withdrawal behaviours like being late or absent, and the final result is an employee switching the company. Additionally, Katavich (2013) cited that it was discovered that the intention to leave comes into a picture much later in the withdrawal process and has been seen to strongly indicate the actual turnover. Because an organization must face potential costs as employees leave, we can argue that it will be in the best interest of an organization to research about how performance appraisals affect an employee's intention to leave by increasing job satisfaction (Brown et al., 2010).

\subsection{Theoretical Framework}

There are some organizations, especially IT companies and banks that consider training and developing their staff as the most effective retaining strategy. The trainers are enthusiastic about investing their time to train employees and consequently, the staffs rarely leave the organization. By influencing the work satisfaction and dedication, training and development impact retention of the employees largely. Therefore, employers must understand the importance of giving appropriate training to the employees for encouraging them to stay in the organization.

Training to the employees gives an optimistic effect on job fulfilment, hence giving the employees an objective to stay within the organization as long as possible. Being trained and learning a new technique and skills required in different departments enable the employees to gain up to date and extensive procedural knowledge. However, knowing the importance of training and development as a retention factor, training managers should use well-structured and well-designed training programme in order to enhance necessary skills and knowledge (Bharwani \& Butt, 2012).

Rewards are considered as thanks giving gesture and acknowledgment representing hard work being paid off by the organization to its employees. With the provision of reward and recognition, employees are highly motivated and also ensure that staff turnover decrease. Past studies highlighted that workers get devoted and dedicated to their workplace every time their 
work is acknowledged and receive rewards against it (Salie \& Schlechter, 2012). Objective of reward strategies is to motivate employees and benefit them in terms of enjoyment in their work. If organizations value there employees and treat them well, then the employees will enjoy their work and generate positive outcomes in terms of excellent services for customers and clients in industries like IT and banking. Furthermore, Tiwari (2015) cited that organizations taking care of their employees automatically ensure adequate customer service and client's satisfaction.

There are many more strategies followed by organizations today. Recruitment strategies and improved quality training activities are some of them. Therefore, employers need to give proper attention to those strategies as well in order to improve the retention rate of employees. Also, there are several methods for enhancing pleasure and commitment towards work and organization respectively. Tiwari (2015) proposed a framework that enlists the aspects that lays under the umbrella of business and organizational attributes such as, working hours far from socialization, low wages, and low skill requirements and so on, which has directly or indirectly effect on personal employee dimensions and work life balance. In upcoming years, if organization would be focusing more on refining and reforming quality and organizational plans and strategies such as advanced recruitment strategies, training and development, relevant learning opportunities, job fit, appropriate education, and employees' work life balance, then it will attain the effective outcome, organizational productivity, and higher employee retention rate (Deery, 2008).

Recruitment has a very significant role in the retention of talented staff. Particularly in IT and banking industry if HR professional, recruitment team and hiring managers compel on acquiring top quality and significant employees, then it will directly benefit the organizational market reputation and image. However, this aim can be accomplished through strategic approach by timely feedback, motivation, empowerment and reducing their workload. The employers should attentively consider the skills, abilities and competencies required to survive in the industries. Most often, recruiters leave the loop by being inadequately strategic regarding this aspect (Deery, 2008).

It is essential not only for HR but for supervisors, managers and team leads to be more creative, willing and imaginative to ensure work life balance for their respective employees. Thus, this approach meets the needs of both employees and organization. A work-life balance approach, as per previous researches seems to be the positive contributor in employee retention. It plays a significant role in shaping a decision of the employee regarding their stay within the organization. Undeniably job commitment and work stress has a noticeable impact on the employees' productivity and performance by contributing to their decision of leaving an organization (Deery, 2008) resulting in a spontaneous increase in turnover rate. 
Independent Variables

Dependent Variable

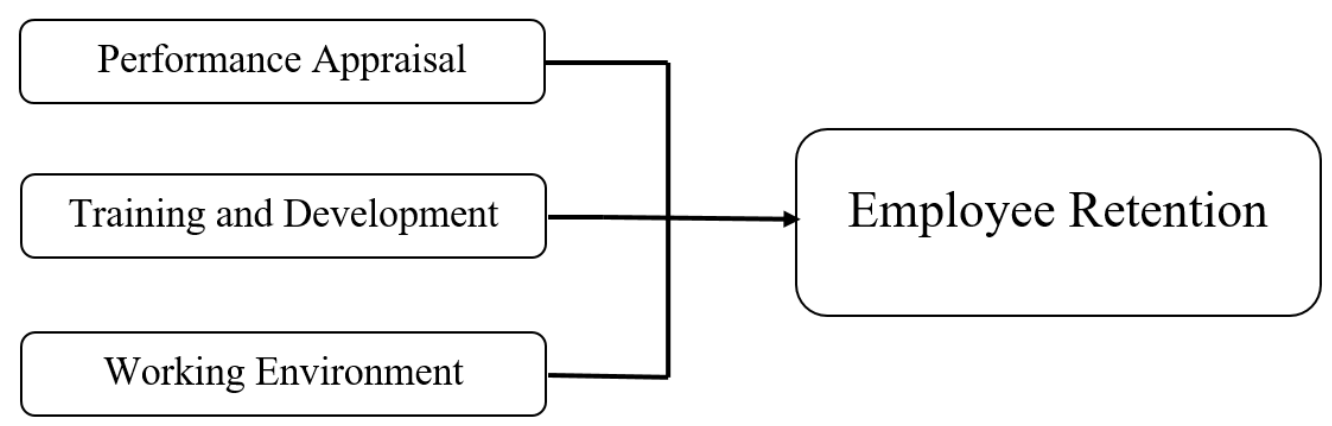

Figure 1. Theoretical Framework

\section{Research Methodology}

The study entails dependent and independent variables to study the interrelationship among them by conducting research on how employees working in Banks and IT companies perceive their retention management. To illustrate, the study attempts to showcase how appraisals, training and working environment (independent variables) satisfy employees and retain them for a longer time period (dependent variable). In a nutshell, the theoretical framework proposed in this study recommends how performance appraisal, training and development and work environment can be interlinked to conclude factors significant for an employee's retention in a firm.

First variable is performance appraisal, of which statements comprise the information about respondent's perception towards the importance of retaining potential employees by managing their performance, their priorities towards the issues raised in the organization about the employee development, and their responsibility to remind team members about the exceptional performance by giving them timely feedback.

Considering second variable training and development, respondents were inquired about their beliefs over their employers whether they invest in their employee's development and learning, their organization's objective assessment of individual's development needs, honesty in giving feedback for employee's developmental purposes, their contribution in creating developmental opportunities for subordinates, and for their time to conduct formal career planning sessions. It was also identified that does the career need of each employees is aligned with the developmental programs that are being offered in the organization.

Another variable considered is work environment which include statements such as whether the organization for which employee work ensures the safety and security of the workers and do they have any such procedures to deal with unforeseen incidents. This section also found out whether respondents being an employee are provided with the basic and additional benefits for their physical strength. Moreover, respondents were also asked to share their experiences regarding physical conditions and facilities provided by their organization and appropriateness of the environment given to them. 
Finally, the dependent variable part that is employee retention comprises of statements that search for the opinions about the effort employees are willing to put into the accomplishment of the organizational goals. The statements further seek for identifying the intention and vision of the employees towards their future in their current organization and degree of loyalty, dedication, and value they hold for their recent workplace.

For data collection self-administered questionnaire was distributed among 150 incumbents, from which 120 responses were received. For analysing the gathered data, regression analysis was used. The Pearson correlation test was used to determine the significant or insignificant relationship amid the retention factors and employee retention. The responses were analysed by using some of the reliable statistical measuring software such as Statistical Package for Social Sciences (SPSS) version 16 and Microsoft excel.

\subsection{Research Design}

The study is a causal one as it pursues to identify cause-and-effect relationship among specific retention factors (independent variables) and employee retention (dependent variable). Moreover, it is categorised as a quantitative research, because it mentions objectives of the research through practical assessments with the involvement of analytical approaches and numerical measurement (Zikmund, Babin, Carr, \& Griffin, 2013). The cross sectional approach is adopted for conducting research which means data is gathered at a single moment in time by the various segments of population that are being sampled (Zikmund et al., 2013).. Two sectors are under the consideration as a setting for research purpose named as Information Technology and Banking sector.

\subsection{Population}

The response rate of the survey is high, as sample size was supposed to be 150 respondents, but the sample size for research finding is 120 respondents among which there are 60 employees employed in IT companies and 60 banking professionals approximately to make the results more valid and reliable. The professionals work in a different department within their respective organizations, such as finance, marketing, human resources, administration, IT and others.

\subsection{Sampling}

For this study, non-probability sampling is used as a sampling technique. According to Zikmund et al. (2013) non-probability sampling is a technique where selections of the sample units are based on convenience or personal judgement. This technique also represents that the probability of choosing any particular member from the population is uncertain. In non-probability sampling, specifically purposive or judgment sampling is adopted for this research which is a method where a qualified individual picks the sample on the basis of their personal judgment regarding sample members' certain characteristics (Zikmund et al., 2013). Also convenience sampling is used which is a sampling procedure in which most conveniently available people or units are obtained (Zikmund et al., 2013). 


\subsection{Questionnaire Design}

Following are the categories describing the components of a questionnaire used as a primary collection tool for conducting research:

\subsubsection{Demographic Characters}

It includes gender, age, qualification, experience, a department, industry, the name of the organization, and a number of employees working in the organization.

\subsubsection{Employee Retention Factors as Independent Variables}

Employee Retention, independent variables adopted in this research are three; Performance appraisal, Training and development, and a work environment which includes 5, 7, and 6 statements respectively. For sustaining the consistency, all three variables were kept in both the models, IT and Banking (Table 2 and 3). The answers of test required from the respondents are set on a Likert, five-value scale (1= Strongly Disagree, 2=Disagree, 3=Neutral, 4=Agree, 5=Strongly Agree).

\subsubsection{Employee Retention Factors as Dependent Variable}

This part of a questionnaire evaluates perspective of people about employee retention within their organization, which include 5 statements. Respondents are provided with the set of five-value, Likert scale for their opinions as discussed above.

\section{Result}

On comparing the values of $\mathrm{t}$ and $\mathrm{p}$ resulted from the data of IT companies and Banking sector, it was spotted that performance appraisal $(t=3.778, p<0.01)$ seems to have a significant impact on employee retention as per employees of IT sectors, whereas in Banks, training and development $(\mathrm{t}=2.073, \mathrm{p}>0.01)$ is the most influencing factor for retaining employees as per employees working in the banks of Karachi. Data also represent that in IT companies, training and development and work environment is considered as less motivating factor to increase the retention rate. Although, in banks it was analysed that after training and development, work environment also influences the employee retention to some extent whereas, performance appraisal has no significant impact on the retention rate of the employees working in the banks of Karachi.

The statistical analysis showed that employee retention was evident in both, IT and Banking sectors, where all three independent variables (performance appraisal, training and development, and work environment) were evident to be an influencing factor to different extents in shaping the employees' decision of staying within the organization. In general, both sectors have a strong history with high and impressive market position nationally and globally. It was statistically proven that a positive relationship between all three retention factors (performance appraisal, training and development, and work environment) and retention rate of employees exist (see Table 1). This analysis agrees with the results of literature. It is obvious that employee satisfaction and growth is one key to obtain employee retention in both IT companies and banks, like elsewhere in the world. In general, 
considering retention factors (Performance appraisal, Training and development and work environment) leads to a significant retention rate of employees within the chosen organizations of Karachi.

\subsection{Reliability Test}

Reliability means the consistency in the results of the questionnaire. It refers to receiving the similar responses or getting the similar results every time researcher repeats the questionnaire with the same population. Reliability shows the high repeatability and internal consistency of the questionnaire.

Analyzing the responses of workers working in the IT sector, the reliability value ranges from $0.64-0.88$, whereas in banking sector, reliability ranges from $0.69-0.89$. The value range is self-explanatory that all the items are internally consistent to proceed the study.

The questionnaire used in this study is highly reliable. The reliability ranges from $0.68-0.88$ for both the sectors. The reliability value of the statements in the performance appraisal, training and development, and employee retention sections are more than 0.8 that is considered as significantly reliable, whereas in working environment, items reliability value is 0.68 which is more than an average reliability.

\subsection{Correlation}

The Pearson correlation calculated by SPSS shows that the independent and dependent variables hold favourable relationship with each other as the values are positive. The value between similar variables like, performance appraisal (horizontally) and performance appraisal (vertically) is 1 . Also, the values showing relation between dependent-dependent variable are positive. Also, the relationship between dependent-independent variable are positive. Therefore, values in Table 1 represent positive and significant relationship among dependent and independent variables.

Table 1. Pearson Correlation (IT and Banking)

\begin{tabular}{l|c|c}
\hline \multicolumn{1}{c|}{ Variables } & IT & Banking \\
\hline Performance Appraisal & 0.560 & 0.362 \\
\hline Training and Development & 0.348 & 0.485 \\
\hline Work Environment & 0.191 & 0.369 \\
\hline
\end{tabular}

\subsection{Regression}

Regression analysis was used to examine the impact of the retention factors on retention. Regression analysis is used for evaluating the effects of one or more than one independent variables towards dependent variable (Zikmund et al., 2013). To show the comparison between IT and banking sectors, the responses of the participants has been analyzed separately. Table 2 and Table 3 represent the values extracted from coefficient table resulted from the regression analysis of the data received from the employees of IT and banking sector respectively on SPSS. 
Table 2. Regression Analysis of IT Sector

\begin{tabular}{l|l|l|l}
\hline Variables & $\mathrm{B}$ & $\beta$ & $\mathrm{p}$ \\
\hline Performance Appraisal & 0.620 & 0.541 & 0.000 \\
\hline Training and Development & 0.008 & 0.008 & 0.955 \\
\hline Work Environment & 0.069 & 0.061 & 0.593 \\
\hline
\end{tabular}

Values in Table 2 represents that in IT companies, of the three variables two are found significantly and positively correlated with employee retention but the strongest is performance appraisal. Training and development and work environment is less likely considered as the motivating factor to increase the retention rate. Those who inclined to think about their performance appraisal as fair and just system tend to hold a positive view in staying longer in the organization.

The $R^{2}$ and Adjusted $R^{2}$ value is extracted from model summary table. The $R^{2}$ column represents the value which indicates how much independent variable that is employee retention factors (Performance Appraisal, Training and Development, and Work Environment) describes the total variation in dependent variable (Employee Retention). In this case, $R^{2}$ is $31.7 \%$ which is significantly variant. Remaining value represents that this model cannot explain $68.3 \%$ of the variation which means that presence of other factors can be used for describing employee retention. $31.7 \%$ of the variance is explained by performance appraisal, training and development, and work environment in employee retention.

The F and sig. values are extracted from the ANOVA table. Sig. and F value is the F-statistic with the associated $\mathrm{p}$-value. The $\mathrm{F}$ test shows that the model has a significant linear relation $[\mathrm{F}(3,56)=8.677, \mathrm{p}<0.01]$. The results reveal that of the three factors (performance appraisal, training and development, and work environment) only performance appraisal independently contributed $(\beta=0.541, p<0.01)$ in retaining employees in the organization.

Table 3. Regression Analysis of Banking Sector

\begin{tabular}{l|l|l|l}
\hline Variables & B & $\beta$ & $\mathrm{p}$ \\
\hline Performance Appraisal & 0.082 & 0.108 & 0.463 \\
\hline Training and Development & 0.281 & 0.332 & 0.043 \\
\hline Work Environment & 0.173 & 0.178 & 0.178 \\
\hline
\end{tabular}

Overall, the model explains $R^{2}=26.6 \%$ of the variance in the employee retention or participants views in employee retention.

Table 3 illustrates that in banks after training and development, work environment also influences the employee retention to some extent whereas performance appraisal has less significant impact on retention rate of the employees working in the banks of Karachi.

The $\mathrm{F}$ value demonstrations that a relationship between the variables discussed in our theoretical framework exists is linear $[\mathrm{F}(3,56)=6.763, \mathrm{p}>0.01]$. The results reveal that of the three factors (performance appraisal, training and development, and work environment) training and development relatively contributed $(\beta=0.332, \mathrm{p}<0.01)$ in retaining employees in the banking sector. The model's p-value is 0.000 which is lower than 0.05 , an alpha value and 
henceforth the F-statistic is evidenced to be significant.

Training and development effect size is comparatively smaller in banking industry but interestingly, performance appraisal is contributing with bigger magnitude in IT sector. On comparing the $\beta$ and $p$ values resulted from the data of IT companies and Banking sector in Table 2 and 3 respectively, it was spotted that performance appraisal seems to have a significant impact on employee retention as per the employees of the IT sectors, whereas in Banks, training and development is the most influencing factor for retaining employees as per employees working in the banks of Karachi. As per this study, variable performance appraisal has relatively more impact on employee retention in general rather than other two remaining independent variables.

\section{Discussion}

The questionnaire designed to conduct the research on employee retention consists of 23 statements each of them is related to the variable introduces in the theoretical framework.

Findings and analysis of collected data concluded that the reliability of the survey lies between $65-85 \%$ which is relatively high. The study has proved that there is a positive correlation between retention factors and employee retention in both IT and banks within Karachi. Employees' who perceive their appraisal systems as unbiased, satisfied with the developmental opportunities and found physical conditions and work environment ergonomic tend to feel loyal with the organization and stay for a longer period of time. Specifically, performance appraisal has significantly strong relationship with employee retention in IT sector as compared to training and development and work environment. However, training and development has proved to be significantly more affective in banking sector. Moreover, many human resource managers while making HR and retention strategies consider retention factors in order to increase the retention rate. Retention factors considered in the study; performance appraisal, training and development and work environment evident to contribute to accelerate retention rate of the employees at different variations. These factors have worked as independent variables in this research through which effect of retention factors on retention rate was identified.

The regression shows the significant impact of certain factors on employee retention. As it was a comparative study amid IT and banking sector, both combine and separate regression analysis was performed. Results showed that performance appraisal has significantly more impact $(\beta=0.280, p<0.01)$ on retention rate of the employees working in both the sectors in general. However, on regressing separately, data from employees of IT sector highlighted the performance appraisal as the most influencing factor for retaining the employees within the organization. The p-value was less than $5 \%$, hence the hypothesis was accepted. Although, other two variables; training and development and work environment proved to have less impact on retention rate therefore, the p-values were more than 0.01 , rejecting the hypothesis.

Findings from regression analysis of data gathered from the employees working in the banks represents that training and development is relatively more influencing over the retention rate of employees. Furthermore, p-value is also found less than 0.01 hence accepting the 
hypothesis. Additionally, work environment seems to influence employee retention in the banks comparatively lower than training and development but higher than performance appraisal. However, p-values of work environment and performance appraisal are higher than 0.01 , hence rejecting both the hypotheses.

According to findings and statistics, retention factors chosen in this study influence significantly to the employee retention in regard to employees' intention to leave, employees' satisfaction, productivity and employee engagement. Either it's a multinational company, manufacturing industry, or banking sector factors like performance appraisal, training and development and work environment plays a pivotal role in making a successful firm, by enriching the organization with the skilled and dedicated workforce for longer period of time.

\section{Recommendation}

The recommendations after conducting the survey and analysing its findings are as follows:

(1) Organizations such as IT companies and banks must consider their employee motivation, engagement and satisfaction prior to their other tasks.

(2) In economic downturn and other crisis, talent will be more beneficial than organization's products or services.

(3) Management must be more concerned about the talent retention in order to fill the vacant key positions because highly dissatisfied and demotivated employees leave the organization when another attractive opportunity arrives to them.

(4) As employee retention has drawn attention rapidly, organizations must focus on developing talent within the organization as talent crisis is expected in the upcoming future.

(5) The organization strategists must formulate employee retention strategy as seriously as they formulate business strategies; this can provide the basis and direction to the HR professionals and line managers in retaining talents.

(6) Strategists and Board members must align employee retention strategies with the core business strategy so that company's vision and mission should be communicated clearly at the bottom level, therefore, leading to the increased employee productivity.

\section{Limitations}

Researcher faced various obstacles while conducting the research, as there were following boundaries:

(1) The study covers only one specific location i.e. Karachi.

(2) It is limited to IT and banking sectors.

(3) The sample size of this survey is up to 120 respondents.

(4) There was a time constraint i.e. a limited time of 12 months.

\section{Conclusion}

Employee retention is a broad term and is escalating with every passing day. There is no 
universal definition of employee retention. Every organization has their own understanding of employee retention according to the nature of operations they perform. So that organizations incorporate that perception with their unique strategy accordingly. Employee retention refers to holding the employees for longer period of time by identifying their needs and priorities. This can be done by formulating certain retention strategies and implementing them accordingly.

Employee retention is getting importance in today's era by becoming more concerned aspect within the organizations. Retention factors can motivate employee and bind talented workforce in a team and through which unusual and serious problems can be resolved much effectively and efficiently. Appropriate utilisation of retention factors can lessen the turnover rate and cost incurred as a result.

Employee retention is although a difficult move for organizations but the organizations need to understand that it is a lasting commitment and thus they must integrate it in the company's general strategy and make it evident in HR management objectives. As there are numerous factors and aspects that directly or indirectly influence the employee retention, organizations should consider these factors and formulate strategies accordingly.

Employee retention aimed to help the organization in achieving its strategic goals by working out the reasons for leaving the organization and factors leading towards the increased dissatisfaction among the employees, which can directly or indirectly help to retain the devoted and loyal talent for the organization. Retention rate is effective when workers are provided with timely feedback and motivational booster. Business knowledge, relevant experience and long-term relationship and familiarity with the organization will lead to the competitive advantage, market share growth; reduce turnover rate, loyal workforce, and satisfied customers.

As this research is about to recognize the effect of retention factors on IT and banking sector which was proven positive through the findings and analysis. It was confirm that certain retention factors and employee retention strategies are being implemented by IT companies and banks as a tool of retaining employees. The survey from 120 employees of IT and banking sector verifies that performance appraisal, training and development and work environment are used more frequently than before for retaining and satisfying employees. HR professionals and managers are considering these factors as crucial contributor for the employee retention.

The study and past researches revealed that money or capital is not the important asset of the organization in real but the workforce and human capital is the actual asset of the organization. For sustainability and survivorship of the organization, talents should be develop and motivate timely. Human resource practitioners should take systematic approach by formulating retention strategies incorporating appropriate retention factors and align them with the core business strategy.

\section{Acknowledgement}

I would like to express my profound gratitude to my research supervisor, Dr. Danish Ahmed Siddiqui. Without his support and supervision this paper would not have been possible. I am thankful, to my family members for their patience and cooperation throughout my research and all of my friends who contributed in my personal and professional growth through their 
wealth of knowledge. I must extend my deepest gratitude to one of my teacher and mentor Ms Bushra Jauhar who have been supporting me persistently and provided rigorous feedback throughout my research work. I am grateful to Ms Mishail Imran, my colleague and Dr Sadia Bhutta, Assistant Professor at Aga Khan University Institute for Educational Development for their unconditional support and technical knowledge they have provided me at every stage of my research work.

\section{References}

Authority, B. (2009). Competitive strategies for a world class workforce. Retrieved March, 14, 2014.

Bharwani, S., \& Butt, N. (2012). Challenges for the global hospitality industry: an HR perspective. Worldwide Hospitality and Tourism Themes, 4(2), 150-162. https://doi.org/10.1108/17554211211217325

Brown, M., Hyatt, D., \& Benson, J. (2010). Consequences of the performance appraisal experience. Personnel review, 39(3), 375-396. https://doi.org/10.1108/00483481011030557

Christensen, H. J., \& Rog, E. (2008). Talent management: A strategy for improving employee recruitment, retention and engagement within hospitality organizations. International Journal $\begin{array}{llll}\text { of Contemporary Hospitality } \quad \text { Management, } & \text { 20(7), }\end{array}$ https://doi.org/10.1108/09596110810899086

Das, B. L., \& Baruah, M. (2013). Employee retention: A review of literature. Journal of Business and Management, 14(2), 8-16.

De Vos, A., \& Meganck, A. (2008). What HR managers do versus what employees value: Exploring both parties' views on retention management from a psychological contract perspective. Personnel review, 38(1), 45-60. https://doi.org/10.1108/00483480910920705

Deery, M. (2008). Talent management, work-life balance and retention strategies. International Journal of Contemporary Hospitality Management, 20(7), 792-806. https://doi.org/10.1108/09596110810897619

Essays, U. (November 2013). A definition of employee retention. from https://www.ukessays.com/essays/management/a-definition-of-employee-retention-managem ent-essay.php?vref=1

Eyster, L., Johnson, R. W., \& Toder, E. (2008). Current strategies to employ and retain older workers: Urban Institute.

Government, W. P. f. W. S. (2015). Employee Retention.

Gruman, J. A., \& Saks, A. M. (2011). Performance management and employee engagement. Human Resource Management Review, 21(2), 123-136. https://doi.org/10.1016/j.hrmr.2010.09.004

Hong, E. N. C., Hao, L. Z., Kumar, R., Ramendran, C., \& Kadiresan, V. (2012). An effectiveness of human resource management practices on employee retention in institute of 
higher learning: A regression analysis. International journal of business research and management, 3(2), 60-79.

Katavich, K. M. (2013). The importance of employee satisfaction with performance appraisal systems: a thesis presented in partial fulfilment of the requirements for the degree of Master of Arts in Psychology at Massey University, Albany, New Zealand. Massey University.

Kossivi, B., Xu, M., \& Kalgora, B. (2016). Study on determining factors of employee retention. Open Journal of Social Sciences, 4(05), 261. https://doi.org/10.4236/jss.2016.45029

Lam, C. L., Law, S. F., Loo, Y. J., Ng, W. Y., \& Ooi, S. L. (2015). A study on factors affecting employee retention in nursing industry at Klang Valley. UTAR.

Loan-Clarke, J., Arnold, J., Coombs, C., Hartley, R., \& Bosley, S. (2010). Retention, turnover and return-a longitudinal study of allied health professionals in Britain. Human Resource Management Journal, 20(4), 391-406. https://doi.org/10.1111/j.1748-8583.2010.00140.x

Mabuza, P. F., \& Proches, C. N. G. (2014). Retaining core, critical \& scarce skills in the energy industry. THE INDIAN JOURNAL OF INDUSTRIAL RELATIONS, 635-648.

Naeem, H., \& Saif, M. I. (2010). Employee empowerment and customer satisfaction: Empirical evidence from the banking sector of Pakistan. African Journal of Business Management, 4(10), 2028-2031.

Nyanjom, C. R. (2013). Factors influencing employee retention in the state corporations in Kenya. unpublished thesis Nairobi: University of Nairobi.

Padmanathan, P., \& Newell, J. N. (2012). Retention factors affecting migrant psychiatrists from low-and middle-income countries. International Psychiatry, 9(1), 13-15.

Salie, S., \& Schlechter, A. (2012). A formative evaluation of a staff reward and recognition programme. SA Journal of Human Resource Management, 10(3), 11. https://doi.org/10.4102/sajhrm.v10i3.422

Samuel, M. O., \& Chipunza, C. (2009). Employee retention and turnover: Using motivational variables as a panacea. African Journal of Business Management, 3(9), 410-415.

Sinha, C., \& Sinha, R. (2012). Factors affecting employee retention: A comparative analysis of two organizations from heavy engineering industry. European Journal of Business and Management, 4(3), 145-162.

Tiwari, I. (2015). An analysis of the factors affecting employee retention and turnover in the Irish hospitality Industry. Dublin, National College of Ireland.

Torrington, D., \& Taylor, S. (2009). Fundamentals of human resource management: managing people at work: Pearson Education.

Yazinski, S. (2009). Strategies for retaining employees and minimizing turnover. Retrieved from York, $N Y$. 


\section{Macrothink}

International Journal of Human Resource Studies

ISSN 2162-3058 2019, Vol. 9, No. 1

Zikmund, W. G., Babin, B. J., Carr, J. C., \& Griffin, M. (2013). Business research methods: Cengage Learning.

Zin, S. M., Ahmad, N., Ngah, N. E. B., Ismail, R. B., Ibrahim, N. B., \& Abdullah, I. H. T. B. (2012). Motivation model for employee retention: Applicability to HRM practices in Malaysian SME sector. Canadian Social Science, 8(5), 8-12.

\section{Copyright Disclaimer}

Copyright for this article is retained by the author(s), with first publication rights granted to the journal.

This is an open-access article distributed under the terms and conditions of the Creative Commons Attribution license (http://creativecommons.org/licenses/by/4.0/). 